\title{
$70^{\mathrm{TH}}$ ANNIVERSARY OF THE DEPARTMENT OF MUSICOLOGY OF THE FACULTY OF MUSIC IN BELGRADE
}

Article received on November $4^{\text {th }} 2018$

Article accepted on November $5^{\text {th }} 2018$

UDC: 378.6:78(497.11)"1947/2017"

$781(497.11)$

\author{
Sonja Marinković* \\ University of Arts in Belgrade \\ Faculty of Music \\ Department of Musicology
}

\section{A JUBILEE OF THE DEPARTMENT OF MUSICOLOGY AT THE FACULTY OF MUSIC IN BELGRADE ${ }^{1}$}

\begin{abstract}
The article sheds light on the work of the Department of Musicology at the Faculty of Music, on the occasion of its jubilee - the $70^{\text {th }}$ anniversary of its foundation. The purpose of the text is to point out the changes that its concept of studying musicology has undergone over the years and introduce its teaching staff and their work in research and teaching. Special attention is devoted to the Department's activities in publishing.

Keywords: Academy of Music / Faculty of Music in Belgrade, Department of Musicology at FoM, musicology, music history, music pedagogy, Serbian music.

\footnotetext{
*Author contact information: sonja.marinkovic@gmail.com

1 Part of the research conducted for the purposes of this text was done under the auspices of Идентитети српске музике у светском културном контексту / Identiteti srpske muzike u svetskom kulturnom kontekstu (Identities of Serbian Music in the Global Cultural Context), a scholarly research project funded by the Ministry of Education, Science, and Technological Development of the Republic of Serbia (project No. 177019).
} 


\section{The Founding of the Department}

The study of musicological disciplines at the university level in Serbia began after World War II, with the establishment of the Divisions of Music History (1948) and Music Folklore (1949) at what was then the Academy of Music in Belgrade, now known as the Faculty of Music at the University of Arts in Belgrade. ${ }^{2}$ Departments (катедра / katedra) as institutions were established much later, in the 1960s; since then, the Department's official designation and staff have undergone a number of changes. ${ }^{3}$ When it comes to the organization of the Department of Musicology (Катедра за музикологију / Katedra za muzikolog$i j u$ ), one may single out four changes as the most significant ones. The first of them refers to the separation of the odsek (одсек, department), comprising the students, and the katedra (катедра, chair), comprising the teaching staff. The second change, from 1994, concerns the Department's official name, replacing the main subjects of study (Section and later Department of Music History and Music Folklore) with the names of the core scholarly disciplines involved (musicology and ethnomusicology). ${ }^{4}$ This stage was inaugurated by separating musicology from ethnomusicology, which also marked the beginning of the implementation of the Bologna Process at the Faculty (2008). The fourth change occurred with the 2016 amendments to the Faculty's statutes, whereby the Departments were redefined so as to include only the professors of the core disciplines. ${ }^{5}$ This saw the exclusion of all the professors of other humanist disciplines,

2 The Academy of Music in Belgrade was founded on 31 March 1937 as Serbia's first state school, offering higher education in music. In 1957, it joined the association of art academies, which were made faculties in 1973, when the Academy acquired its current official name: the Faculty of Music at the University of Arts in Belgrade.

3 Officially, only the teaching staff who work at the Department full-time are included as its members, which means that the Department comprises only a fraction of the teaching staff who work there. Also, the list of subjects taught at the Department has undergone numerous changes, which is further discussed below. Individual professors could teach at multiple departments. For instance, Vlastimir Peričić (Властимир Перичић), who chaired the Department of Music History and Music Folklore for many years, was originally hired and received his academic rank at the Department of Music Theory, because that Department was considered his home department and official place of employment.

4 This should not be viewed as a purely formal decision, since it resulted from some essential interventions in the curriculum, simultaneously involving a major change in the study programme. This involved the replacement of the field of Yugoslav music history with a number of subjects under the heading of National Music History, as well as important innovations in the Department's approach to the teaching of music history, which nonetheless remained the main subject in the musicology programme.

5 The Faculty's statutes (Article 49) contain the following stipulations: "The Faculty may establish departments [катедpe/katedre] focusing on one or more related specific artistic, scholarly, or art-theoretical fields. The Faculty may form a department if it incorporates 
who had been part of the Department not only in the organizational, but also in essential terms, by collaborating with other members of the teaching staff. ${ }^{6}$ This survey of the Musicology Department's work will include these changes but will not, except concerning their shared beginnings, offer information about the activities of the Department (Одсек/Odsek) of Ethnomusicology.

The Department's initial professors were Stana Đurić Klajn ${ }^{7}$ (Стана Ђурић Клајн, 1950-1971), a doyenne of Serbian music historiography and author of the first history of Serbian music; ${ }^{8}$ Petar Konjović (Петар Коњовић, 19391951) ${ }^{9}$ and Nikola Hercigonja ${ }^{10}$ (Никола Херцигоња, 1949-1974), both major

study programmes or modules that offer competences in the specific areas under the purview of that department. A department comprises all teaching staff and fellows appointed in the specific artistic, scholarly, art-theoretical, and expert fields that form its main area". The Faculty statutes are available at http://www.fmu.bg.ac.rs/vazna_dokumenta.php (in Serbian).

6 These disciplines included applied aesthetics, art history, foreign languages, sociology of culture, and, for a time, psychology and pedagogy. The teaching staff in these disciplines formed a separate organizational unit - Division (Oдељење/Odeljenje, Article 62): "The Faculty includes the Division of Subjects in General Education and Expertise. The Division comprises all teaching staff and fellows appointed in specific artistic, scholarly, art-theoretical, and expert fields that require the completion of study programmes that are outside the Faculty's main area of study and expertise".

7 Stana Đurić Klajn (Стана Ђурић Клајн, 1905-1986, née Đurić; her first married name was Ribnikar).

8 The work of Stana Đurić Klajn was extensively researched by Roksanda Pejović (Роксанда Пејовић) and formed the subject of a collection of essays published by the Serbian Musicological Society. Cf. Роксанда Пејовић [Roksanda Pejović], Музиколог Стана Ђурић-Клајн (историографска, есејистичка и критичарска делатност (The Musicologist Stana Đurić Klajn: Her Work in Music Historiography, Prose, and Criticism), Belgrade, Serbian Academy of Sciences and Arts, Institute of Musicology, Composers' Association of Serbia, 1994; Роксанда Пејовић [Roksanda Pejović], Коментари текстова Стане Ђурић-Клајн (Поводом стогодишђњище рођења) (Commentaries on Texts by Stana Đurić Klajn, on the Occasion of Her Centenary), Belgrade, FoM, Department of Musicology, 2008; Мирјана Веселиновић-Хофман and Мелита Милин (Mirjana Veselinović and Melita Milin, eds.), Стана Бурић-Клајн и српска музикологија (Stana Đurić Klajn and Serbian Musicology), Belgrade, SMS, 2010.

9 Petar Konjović (Петар Коњовић, 1883-1970). Konjović worked at the Academy of Music as a full professor of vocal diction, instrumentation, conducting, and the history of the theatre. Since he was instrumental in the 1948 establishment of the Institute of Musicology at the Serbian Academy of Sciences and Arts (Српска академија наука и уметности ) Srpska akademija nauka i umetnosti), serving as its first director, it was only natural that he should take part in the activities of the newly founded Division of Music History. Unfortunately, nothing else is known about this segment of his work.

10 Nikola Hercigonja (Никола Херцигоња, 1911-2000). The musicological work of Nikola Hercigonja was treated in a special collection of essays. Cf. Мирјана Веселиновић-Хофман 
Yugoslav composers and writers on music; Milo Asić11 (Мило Асић, 19501951), as an adjunct professor of Yugoslav music history; Miodrag Vasiljević (Миодраг Васиљевић, 1938-1963), an ethnomusicologist; and Dr. Marija Koren $^{12}$ (Марија Корен, 1969-1972), a musicologist. The Department's first professors, until Marija Koren, did not hold doctoral degrees, even though at Serbian universities, in the humanities, this was required as a prerequisite for admission in all academic ranks, ${ }^{13}$ reflecting not only a lack of personnel, but also a conception of studying music history influenced by the Soviet Union, ${ }^{14}$ where the study of musicology was allocated to higher schools of music rather than faculties of philosophy.

The establishment of the Department of Music History and Music Folklore was extremely important for the development of these scholarly disciplines in Serbia, because it enabled the beginning of the continuous training of scholars in these areas. The beginnings were quite modest. The first few generations produced only a handful of graduates: by 1961-62 only 11 and by the end of the 1960 s, just five more. Only a fraction of them pursued scholarly careers. These were Dr. Miloš Velimirović (Милош Велимировић, 1922-2008), a leading figure in Byzantine studies worldwide, who spent his career in the United States; Dr. Dragoslav Ortakov (Драгослав Ортаков, b. 1928), a renowned Macedonian musicologist; Dr. Roksanda Pejović (Роксанда Пејовић, 1929-2018) and Dr. Dimitrije Stefanović (Димитрије Стефановић, b. 1929), two doyens of Serbian musicology; and Dr. Marija Koren, who, upon completing her education in Belgrade and Leningrad (now St. Petersburg, Russia), began her teaching career at the Academy of Music in Belgrade and then transferred to the Faculty of Philosophy in Ljubljana.

and Мелита Милин (Mirjana Veselinović Hofman and Melita Milin, eds.), Никола Херичгоња (1911-2000) - човек, дело, време (Поводом 100 година од рођења) (Nikola Hercigonja (1911-2000): The Man, His Work and Time), Belgrade, SMS, 2011.

11 Milo Asić (Мило Асић, 1916-1980).

12 Marija Koren (Марија Корен, 1937, married Bergamo). The Slovenian Musicological Annual marked several jubilees of Marija Bergamo and the New Sound has published an interview with her. Cf. Zoran Krstulović, "Bibliografija Marije Bergamo" (Bibliography of Marija Bergamo), Muzikološki zbornik / Musicological Annual, XLIII/2, 2007, 399-456; Leon Stefanija, REČ MUZIKOLOGA: "A Conversation with Marija Bergamo", New Sound, 35, 2010, 5-16.

13 Serbia's first doctor of philosophy in the field of musicology was Miloje Milojević (Prague, 1925), who acquired his degree precisely in order to qualify as a professor at the Faculty of Philosophy of the University of Belgrade.

14 Following the end of World War II, in 1945, the Academy of Music adopted the Soviet model of music education, envisaging seven years of study. But in 1948 it reverted to the earlier conception. 


\section{The 1970s and the 1980s}

The Department's development accelerated in the early 1970s, when numerous changes occurred. At that time, the following appointments were made: Vlastimir Peričić ${ }^{15}$ (Властимир Перичић, 1971-1993) for Yugoslav music history and Dr. Mirjana Veselinović Hofman ${ }^{16}$ (Мирјана Веселиновић Хофман, 19732016) for general music history, Dr. Roksanda Pejović (1975-1995), Dr. Nadežda Mosusov $^{17}$ (Надежда Мосусов, 1977-1994), Dr. Sonja Marinković ${ }^{18}$ (Соња Маринковић, 1981); Dr. Zoran Gavrilović (Зоран Гавриловић, 1970-1971) for aesthetics, later renamed to "history of philosophy with aesthetics" and taught by Dr. Milan Damnjanović19 (Милан Дамњановић, 1978-1989); Dr. Dragoslav Dević20 (Драгослав Девић, 1962-1990) and Dr. Dimitrije Golemović21

\footnotetext{
15 Vlastimir Peričić (Властимир Перичић, 1927-2000). For more on Vlastimir Peričić's work in musicology, see Дејан Деспић [Dejan Despić], "Разговор са Властимиром Перичићем" (A Conversation with Vlastimir Peričić), Нови звук [Novi zvuk], 2, 1993, 5-10; Марија Масникоса [Marija Masnikosa], "Музиколошки опус Властимира Перичића" (The Musicological Oeuvre of Vlastimir Peričić), Нови звук, 10, 1997, 33-46.

16 Mirjana Veselinović Hofman (Мирјана Веселиновић-Хофман, b. 1948). Her work is discussed in the following interview: Tijana Popović Mlađenović, "Living One's Own Thought Experience with Music and Musicology - Interview with Mirjana VeselinovićHofman", New Sound, 41, 2013, 5-25. Although in surveys of this kind it is ill-advised to single out individual contributions, the members of the Department are in full agreement that when it comes to the development of the Department of Musicology, the contribution of Mirjana Veselinović Hofman has been fundamental. She was the leader of every research project pursued at the Department, its chair for a number of years, its representative on the main committee of the ministry responsible for higher education, the initiator and editor of this journal, a committed and dedicated pedagogue who supervised a large number of dissertations and a wide range of specializations pursued by members of the Department (not only at the University of Arts in Belgrade). The standards she set in her work in research and scholarship constitute a model and professional obligation. That is why celebrating this jubilee of the Department of Musicology was conceived as a sort of recognition of its most deserving member. That is likewise demonstrated by a massive collection of essays that the Department published to mark her $70^{\text {th }}$ birthday. Cf. Sonja Marinković et al. (eds.), Essays in Honor of Prof. Dr. Mirjana Veselinović-Hofman/Izazovi savremene muzikologije. Eseji u čast prof. dr Mirjane Veselinović-Hofman, Belgrade, FoM, 2018.

17 Nadežda Mosusov (Надежда Мосусов, 1928). Although Prof. Mosusov's main institution where she was employed full time was the Institute of Musicology at the Serbian Academy of Sciences and Arts, her many years of teaching at the Department of Musicology left a deep mark.

18 Sonja Marinković (Соња Маринковић, b. 1954).

19 Milan Damnjanović (Милан Дамњановић, 1924-1994).

20 Dragoslav Dević (Драгослав Девић, 1925-2017).

21 Dimitrije Golemović (Димитрије Големовић, b. 1954).
} 
(Димитрије Големовић, 1979) for music folklore. There was a significant increase in the number of students, which is compellingly demonstrated by the number of graduates: between the Department's establishment and 1996 it produced 79 graduates, while a total of 218 students graduated from the Department of Musicology by 2017.

In the academic year of 1977/78 the musicology study programme was, due to its wide scope, extended to five years, with the final, fifth year dedicated to the study of $20^{\text {th }}$-century music, Yugoslav and international alike, with only two more subjects (Методика теоријске наставе / Metodika teorijske nastave Methodology of Teaching Music Theory ${ }^{22}$ and Историја филозофија са естетиком / Istorija filozofije sa estetikom - History of Philosophy with Aesthetics), followed by another academic year for writing the final thesis. The curriculum comprised 54 two-semester courses, including the two core subjects, general music history (in all five years) and Yugoslav music history (in the final three years), with eight mandatory seminar papers in the core subjects. Also, the musicology study programme included a diversified curriculum in the domain of music theory (formal analysis, counterpoint, harmonic analysis), orchestration (with optional practice sessions in composition), practical music courses (piano, score reading, choir, solfège), as well as a group of subjects in the humanities: aesthetics / history of philosophy / applied aesthetics, sociology of culture, psychology, pedagogy, and foreign language) and two more subjects Introduction to National Defence and Marxism. The ensuing years saw an effort to reduce the number of courses in order to alleviate the students' burden and increase the efficiency of the programme, but the number of courses never went below 44 (that is, 88 one-semester courses). The demands concerning the final thesis in musicology were quite high (the required scope was around 100 to over 200 pages of text), often with a pronounced scholarly character, yielding an original contribution to the discussion of various issues in general and national music history. That this quality did not go unnoticed is affirmed by a collection of six final theses, jointly published by the Faculty and the Composers' Association of Serbia. ${ }^{23}$ Research conducted by B.A. and M.A. students was selectively published in Serbia's leading musicological journals at the time

22 The subject's contents revolved around methodology issues in the teaching of an array of subjects in secondary schools of music, including music history. Following the reform, the methodology courses underwent significant further development, and issues in the methodology of teaching music history are now taught in the master's programme as a separate two-semester course.

23 These were the final theses of Marija Kovač (Марије Ковач), Zorana Radić (Зорана Радић), Milica Gajić (Милице Гајић), Sanja Grujić (Сања Грујић), Snežana Nikolajević (Снежана Николајевић). 
Marinković, Sonja: A Jubilee of the Department of Musicology at the Faculty of Music...

(Звук/Zvuk, Нови звук / Novi zvиk, Зборник Матице српске за сиенске уметности и музику / Zbornik Matice srpske za scenske umetnosti i muziku). However, changes were evident primarily in the Department's efforts to encourage its students, right from the beginning, to engage in scholarly research, allowing the Department to establish the nucleus of future research activities at the Faculty of Music. The Department of Musicology (up until 2005, when the new Higher Education Act was adopted) was the only one that applied scholarly criteria in the conferral of academic rank and made an intense effort to cultivate and develop research.

In order to secure the publication of outstanding seminar papers, essays, and reviews produced by its students, the Faculty established an academic journal run by students, Музика и реч / Mиzika i reč (Music and Letters; between 1971 and 1979, 11 issues came out), for the most part edited by students of musicology and ethnomusicology. Works by young aspiring musicologists were also published in $4 \Phi / 4 F$, a journal published by the University of Arts in Belgrade. Later, student papers were published in special-issue collections.

Two of those collections appeared in 1985: the first was titled Барок $u$ рококо / Barok i rokoko (Baroque and Rococo); the second collection comprised essays on the work of Stevan Hristić (Стеван Христић), marking the centenary of the composer's birth. The third collection, from 1986, comprised a selection of essays on the compositional oeuvre of Petar Krstić. The fourth collection appeared in 1988 to mark the Faculty's centenary, bringing a selection of papers by first- and second-year students under the title of Музика $y$ античким и средњовековним еповима / Muzika u antičkim i srednjovekovnim epovima (Music in Ancient and Medieval Epics). Hosting the $15^{\text {th }}$ symposium of the music academies of Yugoslavia in 1989, the Faculty published a collection of essays by students from across the country that had been presented at musicology, ethnomusicology, and music theory conferences in 1988. The next two collections were dedicated to the oeuvres of Kosta Manojlović (1990) and Stanislav Binički (1991).

To enable as many of its successful students as possible, upon graduating, to pursue further work and study in research and scholarship in master's and doctoral studies and then independently, the Department established its Sound Archive, allowing for the preservation and scholarly treatment of sound materials, autographs, and transcriptions by Yugoslav composers as well as a wealth of recorded materials for ethnomusicological research. The topics of graduate and doctoral studies in musicology and ethnomusicology at the Department have been part of research projects funded by the Ministry and headed by members of the Department. The first two projects were titled Развој и остварењ 
српске уметничке музике / Razvoj i ostvarenja srpske umetničke muzike (The Development and Achievements of Serbian Art Music) and Карта дијалеката музичке и орске народне традииије Србије / Karta dijalekata muzičke i orske narodne tradicije Srbije (Mapping the Dialects of Serbia's Music and Oro Traditions). The Department has continually participated in research projects funded by the Ministry of Science; so far, it has completed the following projects: Историја и естетика српске музике / Istorija i estetika srpske mиzike (The History and Aesthetics of Serbian Music, 1993-1996); Српска народна и уметничка музика / Srpska narodna i umetnička muzika (Serbian Folk and Art Music, 1997-2000); Српска музика и европско музичко наслеђе / Srpska muzika i evropsko muzičko nasleđe (Serbian Music and European Music Heritage, 2001-2005); Светски хронотопи српске музике / Svetski hronotopi srpske muzike (The World Chronotopes of Serbian Music, 2006-2010), Идентитети српске музике у светском културном контексту / Identiteti srpske muzike u svetskom kulturnom kontekstu (Identities of Serbian Music in the Global Cultural Context, 2011-2017). The support that the Ministry provided to these projects in primary research allowed for a rather rich production. The Department was able to publish individual and collective monographs, academic conference proceedings, the journal Нови звук/New Sound, collections of student papers, and master's and doctoral theses by students of musicology. It organized national and international conferences and symposia, visiting lectures by renowned international scholars and professors, thus developing a strong platform for promoting its research results.

Starting in 1987, the Department hosted biennial international symposia titled Фолклор и юегова уметничка транспозищија / Folklor i njegova umetnicka transpozicija (Folklore and its Transposition in Art) and published conference proceedings under the same title (Vols. I-III) in 1987, 1989, and 1991.

In April 1995 the symposium took place for the fourth time, as a national conference, and its proceedings were published under the title of Музика кроз мисао / Muzika kroz misao (Music through Thought, 2002). The fifth symposium was held under the heading of Фолклор - музика - дело/Folklore - Mиsic - Work of Art and addressed two main topics: Фолклор и негова уметничка mранспозиција / Folklor i njegova umetnička transpozicija (Folklore and its Transposition in Art) and Идентитет и алтеритет уметничког дела / Identitet $i$ alteritet umetničkog dela (Identity and Alterity of the Work of Art) and its proceedings were published in separate collections in Serbian and English. In 1997 another conference took place under the title of Изузетност $u$ canocmojare/Exclusivity and Coexistence, featuring presentations by over 40 participants from Serbia and abroad. 
Marinković, Sonja: A Jubilee of the Department of Musicology at the Faculty of Music...

The Department organized two musicology conferences in collaboration with the Musicology and Ethnomusicology Section of the Composers' Association of Serbia: Милоје Милојевић - композитор и музиколог / Miloje Milojević - kompozitor i muzikolog (Miloje Milojević - Composer and Musicologist) in 1986 and Aспекти интерпретаиије / Aspekti interpretacije (Aspects of Interpretation) in 1988, both of which were then complemented by the publication of eponymous essay collections. In 2016, the Department co-organized a symposium on the work of Pavle Stefanović (Павле Стефановић) and its conference proceedings came out in 2017.

\section{The 1990s}

The 1990s saw the beginning of a new stage in the development of the Department. It was marked by a significant increase in the number of teaching staff and fellows and the change of the Department's name mentioned above (applying to both the odsek and the katedra) to the "Department of Musicology and Ethnomusicology", a change that was not only formal in nature but that also, using the names of the disciplines, as is customary across the world, unequivocally expressed the scholarly and research orientation of its study programmes. The Department (каmedpa/katedra) of Music History admitted Dr. Tijana Popović Mlađenović (Тијана Поповић Млађеновић, 1989), Dr. Marija Masnikosa (Марија Масникоса, 1990), Dr. Vesna Mikić (Vesna Mikić, 1991), Dr. Dragana Stojanović Novičić (Драгана Стојановић Новичић, 1992), Dr. Tatjana Marković (Татјана Марковић, 1996-2012), Dr. Ivana Perković (Ивана Перковић, 1995), Dr. Dragana Jeremić Molnar (Драгана Јеремић Молнар, 2004), Dr. Biljana Leković (Биљана Лековић, née Срећковић/Srećković, 2008), and Dr. Ana Stefanović (Ана Стефановић), who had been a member of the Faculty since 1991 but officially joined the Department of Musicology only in 2017, although she had already participated in teaching core subjects from an earlier point. Dr. Ivana Miladinović Prica (Ивана Миладиновић Прица, 2008), Marina Marković (Марина Марковић, 2012), Dr. Ivana Petković (Ивана Петковић, 2012), Dr. Radoš Mitrović (Радош Митровић, 2014), and Stefan Cvetković (Стефан Цветковић, 2011) were also engaged as fellows, as well as a number of master's and doctoral students (Valentina Radoman [Валентина Радоман], Adriana Sabo [Адриана Сабо], Bojana Radovanović [Бојана Радовановић], Neda Kolić [Неда Колић], and Milica Petrović [Милица Петровић]).

The body of subjects in the humanities included in the Department has been taught by the following professors and scholars: Applied Aesthetics and Art Theory - Dr. Dušan Pajin (Душан Пајин, 1990-1996), Dr. Miodrag 
Šuvaković (Миодраг Шуваковић, 1996-2015), and Dr. Sanela Nikolić (Санела Николић, from 2012). Psychology and Pedagogy were taught by Dr. Zoran Jovanović (Зоран Јовановић, 1950-1956), Dr. Svetozar Rančić (Светозар Ранчић, 1951-1952), Dr. Ksenija Radoš (Ксенија Радош, 1974-2005), Dr. Vlastimir Miljković (Властимир Миљковић, 1975-1976), Dr. Tijana Kosanović (Тијана Косановић, 1977-78), and Dr. Blanka Bogunović (Бланка Богуновић, from 2006). The history of art has been taught by Dr. Stanislava Kolarić (Станислава Коларић, 1948-1949), Vlado Mađarić (Владо Мађарић, 1950-1959 and 1962-1963), Dr. Pavle Vasić (Павле Васић, 1964-1976), Branka Pecarski (Бранка Пецарски, 1978-1979), Živko Brković (Живко Брковић, 1980-83), Hristina Lisičić (Христина Лисичић, 1984-86), Dr. Slobodan Mijušković (Слободан Мијушковић, 1986-1990), Dr. Jasmina Čubrilo (Јасмина Чубрило, 2002-2013), and Dr. Nikola Dedić (Никола Дедић, since 2014). Introduction to Social Studies and Sociology of Art has been taught by Dr. Ana Jurić-Žilić (Ана Јурић-Жилић, 1960), Dr. Miloš Samardžija (Милош Самарџија, 1960-1962), Dr. Milan Ranković (Милан Ранковић, 1964-1973), Dr. Smiljan Lazin (Смиљан Лазин, 1974-87), and Rada Drezgić (Рада Дрезгић, since 2008); English has been taught by Zorica Despić (Зорица Деспић, 1974-1976), Dr. Ileana Čura (Илеана Чура, 1977-1979), Višnja Ćorović (Вишња Ћоровић, 1979-1990), Milena Erdeljan (Милена Ердељан, 1980-1981), Milijana Grkajac, M.А. (Милијана Гркајац, since 1993), and Jelena Spremić (Јелена Спремић, since 2008); German has been taught by Rade Pavićević (Раде Павићевић, 1950-1955) and Zorana Kozomarić (Зорана Козомарић, since 1993).

The programme and titles of the core subjects in the musicology curriculum underwent further major changes in 1994 as a consequence of the break-up of Yugoslavia. Topics that had been studied under the heading of Yugoslav Music History were transferred, albeit in a significantly condensed form, to General Music History, while Yugoslav Music History was itself replaced by National Music History. The core subjects saw the formation of individual courses for studying the traits of individual styles and epochs and there was increased specialization of individual professors for specific areas, as is customary in the teaching of art history. Efforts were still made to further alleviate the students' burden, which was still quite heavy, with five years of study and an additional year for the final thesis. 


\section{The Opening Decades of the New Millennium}

Further increasing the efficiency (if not the quality) of studying musicology was likewise the purpose of the Bologna reform, for which the ground was set with the Higher Education Act of 2005. All university-level programmes of study were transformed so as to include two cycles with three levels of studies: bachelor's (undergraduate academic studies), master's, and doctoral, amounting to 300 (B.A. + M.A.) + 180 (Ph.D.) ECTS credits. At the Faculty of Music, all study programmes acquired the same structure, with the first cycle comprising $240+60$ and the second 180 ECTS credits. Also, the Faculty used this opportunity to organize specialist studies as well (60 ECTS credits following a master's degree, as part of the second level), but at the Department of Musicology this type of specialization was deemed unnecessary. However, members of the Department's teaching staff contribute to this type of training by participating in specialist artistic programmes where they teach most of the academic courses in general education and conduct the courses in methodology.

The process of implementing the Bologna principles is lengthy and unremitting. It entailed the modularization of the courses and implementation of the European Credit Transfer and Accumulation System (ECTS). All subjects were transformed into one-semester modules with the final examination at the end of every semester. The core group of subjects in the first two years of the programme were allocated 24 ECTS credits, while the same group of courses carries a total of 80 credits in the third and fourth year ( 40 credits in each year). Just how fundamental these changes were may be shown by comparing the current curriculum structure with the structure as it was before the reform. Back then, the programme, in five academic years, comprised 46 two-semester courses, including 54 one-semester courses in the core subjects - general music history and national music history. Following the implementation of the reform, the musicology study programme became simpler. The final thesis is now part of the programme's fifth year, there are (only) 30 courses in the core subjects (with mandatory seminar papers), with a proportionate decrease in the number of courses in the remaining subjects as well, although the conception of the programme and its disciplines have all been retained. The number of students has grown (the programme is accredited for ten students in the first two levels and another four in the doctoral programme). The first generation of students admitted into the newly accredited, reformed programme matriculated in the academic year of 2008/9. The second accreditation cycle saw certain changes, the most essential of which concerned "amalgamating" the courses, because in the humanities (and the University of Arts as a whole) fragmentation did not yield positive results. 
After the 1990s, the Department intensified its research and publishing activities. The Department's traditional international symposia, following a hiatus of several years, were resumed, regularly alternating between round-tables and national-level conferences, which are as significant because they address important issues in Serbian music history. Every symposium has been complemented by the publication of its conference proceedings, whether bilingual or entirely in English: Музика и медији/Music and Media (2004), Music \& Networking (2006), Musical Culture \& Memory (2008), (Auto)Biography as Musicological Discourse (2010), Between Nostalgia, Utopia, and Realities (2012), Identities: The World of Music in Relation to Itself (2012), Music Identities on Paper and Screen (2014), MUSIC/IMAGE: Transpositions, Translations, Transformations... (2018). Nationally significant essay collections published by the Department since the 1990s include Oпера од обреда до уметничке форме / Opera od obreda do umetničke forme (Opera, from Ritual to an Art Form, 1999), Музика кроз мисао / Muzika kroz misao (Music through Thought, 2002), Човек и музика - у част Драгослава Девића / Čovek i muzika - u čast Dragoslava Devića (Man and Music - In Honour of Dragoslav Dević, 2003), Музиколошке и етномузиколошке рефлексије (радови са скупа одржаног 2003) / Muzikološke i etnomuzikološke refleksije (radovi sa skupa održanog 2003) (Musicological and Ethnomusicological Reflexions (works presented at the 2003 symposium, 2006), Историја и мистерија музике - у част Роксанде Пејовић / Istorija i misterija muzike - u čast Roksande Pejović (The History and Mystery of Music - In Honour of Roksanda Pejović, 2006), Мокрањиу на дар / Mokranjси na dar (An Offering to Mokranjac, 2006), Allegretto giocoso - стваралачки опус Миховила Логара / Allegretto giocoso - stvaralački opus Mihovila Logara (Allegretto giocoso - The Creative Oeuvre of Mihovil Logar, 2008), Тематски потениијали лексикографских јединииа о музичким институиијама / Tematski potencijali leksikografskih jedinica o muzičkim institucijama (The Thematic Potentials of Lexicographic Units on Musical Institutions, 2009).

Also, the Department has completed a major project, Историја српске музике: српска музика и европско музичко наслеђе / Istorija srpske muzike: srpska muzika i evropsko muzičko nasleđe (History of Serbian Music: Serbian Music and European Musical Heritage, 2008), a large-scale (785 pages), problem-based survey of various issues in the history of Serbian music and styles, the development of its genres and institutions. The Department also published this journal, the New Sound/Hови звук international journal of music in English (paper) and Serbian (online).

Also, the Department continued publishing its students' seminar papers and final theses. Selections of these were published in the collections titled $O \partial$ Платона до Џона Зорна / Od Platona do Džona Zorna (From Plato to John 
Marinković, Sonja: A Jubilee of the Department of Musicology at the Faculty of Music...

Zorn, 2008), Ликови и лица музике / Likovi i lica muzike (Faces and Characters of Music, 2010), Музиколошке перспективе 1 и 2 / Muzikološke perspektive 1 i 2 (Musicological Perspectives $1 \& 2$, 2012), two electronic collections published online (Музички идентитети и европска перспектива: интердисииплинарни пристуn / Muzički identiteti i evropska perspektiva: interdisciplinarni pristup (Musical Identities and the European Perspective: An Interdisciplinary Approach) and 3борник / Zbornik (Essay Collection), both resulting from the eponymous project/module implemented from 2014 to 2017 at the Musicology Department of the Faculty of Music in Belgrade under the leadership of Prof. Mirjana Veselinović Hofman and supported by the European Union's Jean Monnet Programme and the Ministry of Culture and Information of the Republic of Serbia; in 2017, the project was continued under the leadership of Dr. Marija Masnikosa). The Department also published a series of final/master's theses, by Ivana Petković, Igor Radeta (Игор Радета), Nataša Turnić Đorđić (Наташа Турнић Ђорђић), Biljana Srećković, Ivana Miladinović Prica, and Smiljka Milosavljević (Смиљка Милосављевић). To mark its jubilee, the Department sponsored the electronic publication of additional, newer works in two editions: Wunderkammer/Soba čudesa and Their Masters' Voice.

The members of the Department of Musicology at the Faculty of Music in Belgrade seek to cultivate a diversified and rich scholarly activity and work hard to promote Serbian music scholarship both in Serbia and abroad. That their efforts have not gone unnoticed is perhaps best affirmed by the high level of the Department's biennial international symposia, which regularly attract scholars from all over the world, as well as its productive international collaboration pursued as part of its Erasmus + projects.

\section{Works cited}

Веселиновић-Хофман, Мирјана и Мелита Милин (уреднице): Стана Ђурић-Клајн и српска музикологија. Београд: МДС, 2010. / Veselinović Hofman, Mirjana and Melita Milin (eds.): Stana Đurić Klajn i srpska muzikologija. Belgrade: MDS, 2010.

Веселиновић-Хофман, Мирјана и Мелита Милин (уреднице): Никола Хериигоња (1911-2000) - човек, дело, време (Поводом 100 година од рођења). Београд: МДС, 2011. / Veselinović Hofman, Mirjana and Melita Milin (eds.): Nikola Hercigonja (1911-2000) - čovek, delo, vreme (Povodom 100 godina od rođenja). Belgrade: MDS, 2011.

Деспић, Дејан: „Разговор са Властимиром Перичићем”, Нови Звук, 2, 1993, 5-10. /

Despić, Dejan: "Razgovor sa Vlastimirom Peričićem”, Novi zvuk, 2, 1993, 5-10.

Krstulović, Zoran: "Bibliografija Marije Bergamo”, Muzikološki zbornik, XLIII/2, 2007, 399-456. 
Stefanija, Leon: “A Conversation with Marija Bergamo”, New Sound, 35, 2010, 5-16.

Масникоса, Марија: „Музиколошки опус Властимира Перичића”, Нови Звук, 10, 1997, 33-46. / Masnikosa, Marija: "Muzikološki opus Vlastimira Peričića”, Novi zvuk, 10, 1997, 33-46.

Пејовић, Роксанда: Музиколог Стана Ђурић-Клајн (историографска, есејистичка и критичарска делатност. Београд: САНУ, Музиколошки институт, Удружење композитора Србије, 1994. / Pejović, Roksanda: Muzikolog Stana Đurić-Klajn (istoriografska, esejistička i kritičarska delatnost). Belgrade: SANU, Muzikološki institut, Udruženje kompozitora Srbije, 1994.

Пејовић, Роксанда: Коментари текстова Стане Бурић-Клајн (Поводом стогодишњище рођења). Београд: ФМУ, Катедра за музикологију, 2008. / Pejović, Roksanda: Komentari tekstova Stane Đurić-Klajn (Povodom stogodišnjice rođenja). Belgrade: FMU, Katedra za muzikologiju, 2008.

Popović Mlađenović, Tijana: “Living One’s Own Thought Experience with Music and Musicology - Interview with Mirjana Veselinović-Hofman”, New Sound, 41, 2013, 5-25.

Статут Факултета музичке уметности, доступан на http://www.fmu.bg.ac.rs/vazna dokumenta.php. / Bylaws of the Faculty of Music, available at http://www.fmu.bg. ac.rs/vazna_dokumenta.php.

\section{Summary}

The article sheds light on the activities of the Department of Musicology at the Faculty of Music in Belgrade on its jubilee - the $70^{\text {th }}$ anniversary of its founding. The aim is to highlight the changes that have, over the years, shaped its conception of studying musicology and introduce its teaching staff and their activities in scholarship and pedagogy. The Department's development is surveyed in four stages. The first stage took place from the establishment of the Department until the early 1970s; the second stage was marked by a sharp turn in its teaching programme concerning national music, which occurred following the breakup of Yugoslavia (beginning in 1994); the third stage was marked by the onset of the implementation of the Bologna reform (2008); finally, the fourth stage began with structural changes in the organization of the Department whereby other disciplines in the humanities were formally excluded from it (2016). The text highlights the most significant changes in the Department's teaching plans and musicology study programmes, with a special focus on its activities in publishing. 
Чланак примљен 4. новембра 2018.

Чланак прихваћен 5. новембра 2018.

\author{
Сова Маринковић* \\ Универзитет уметности у Београду \\ Факултет музичке уметности \\ Катедра за музикологију
}

\title{
ЈУБИЛЕЈ КАТЕДРЕ ЗА МУЗИКОЛОГИЈУ ФАКУЛТЕТА МУЗИЧКЕ УМЕТНОСТИ У БЕОГРАДУ 1
}

\begin{abstract}
Апстракт: У раду се осветљава делатност Катедре за музикологију Факултета музичке уметности поводом јубилеја, 70 година од оснивања. Циљ је да се покажу промене у концепту студија музикологије, представе наставници Катедре и њихова научно-истраживачка и педагошка делатност. Посебна пажња посвећена је издавачкој делатности Катедре.

Кључне речи: Музичка академија/Факултет музичке уметности у Београду, Катедра за музикологију ФМУ, музикологија, историја музике, музичка педагогија, српска музика.
\end{abstract}

\section{Оснивање}

Изучавање музиколошких дисциплина на универзитетском нивоу у Србији почиње после Другог светског рата оснивањем Одељења за историју музике (1948) и музички фолклор (1949) на београдској Музичкој академији, данас Факултету музичке уметности у склопу Универзитета уметности. ${ }^{2}$ Институција катедре је формирана знатно касније, крајем шездесетих година XX века, а током историјата више пута је мењала и назив и састав чланова. ${ }^{3}$ Када је у питању организација Катедре за музикологију могу се издвојити четири најзначајније промене. Прва се односи на поменуто раздвајање одсека (који чине студенти)

* Ауторкина контакт адреса: sonja.marinkovic@gmail.com

${ }^{1}$ У раду је представљен део истраживања на пројекту Идентитети српске музике у светском културном контексту (ев. бр. 177019) који финансира Министарство просвете, науке и технолошког развоја Републике Србије.

${ }^{2}$ Музичка академија у Београду основана је 31 . марта 1937. године као прва државна висока школа у Србији. Од 1957. делује у саставу асоцијације уметничких академија, које ранг факултета добијају 1973. године и од тада ова висока школа ради под именом Факултет музичке уметности Универзитета уметности у Београду.

${ }^{3}$ У рад катедре се укључују само наставници са пуним радним временом, тако да она обухвата само део ангажованих предавача. Такође, мењали су се предмети који су бивали обухваћени једном катедром, о чему ће више речи бити у даљем тексту. Поједини наставници су могли радити на више катедара. Тако је, рецимо, Властимир Перичић, дугогодишњи шеф Катедре за историју музике и музички фолклор, био биран на Катедри за теорију музике, јер је она сматрана његовом матичном катедром и на њој је такође био ангажован. 
и катедре (коју образују наставници). Друга, из 1994, тиче се промене назива Катедре која је подразумевала да се у имену одустане од првобитног навођења главних предмета изучавања (Одељење за историју музике, односно музички фолклор, односно Катедра за историју музике и музички фолклор) и преузму имена научних дисциплина (музикологија и етномузикологија). ${ }^{4}$ Трећа етапа је означена организационим раздвајањем музикологије и етномузикологије што означава и почетак примене болоњских принципа студирања на Факултету (2008). Четврта долази са статутарним променама из 2016. године, којима су Катедре дефинисане тако да укључују само наставнике матичних дисциплина. 5 Тиме су из њеног састава изузети наставници предмета који припадају другим хуманистичким наукама а до тада су биле њен део организационо, али и суштински, кроз међусобну сарадњу наставника и сарадника. ${ }^{6}$ У прегледу рада Катедре за музикологију биће праћене ове промене, али ће, осим у вези са заједничким почецима, подаци везани за делатност Одсека и Катедре за етномузикологију бити изостављени.

Први наставници на одсеку били су Стана Ђурић-Клајн ${ }^{7}$ (1950-1971), доајен српске историографије, писац прве историје српске музике, ${ }^{8}$ Петар Коњовић ${ }^{9}$ (1939-1951) и Никола Херцигоња ${ }^{10}$ (1949-1974), значајни југословенски композитори и музички писци;

\footnotetext{
${ }^{4}$ Ову одлуку не треба сматрати формалном, већ је она била последица суштинских захвата у курикулум, јер је истовремено дошло до битне промене наставних планова и програма. Тада је област југословенске историје музике замењена предметима означеним као Национална историја музике, а битно је иновиран и приступ изучавању историје музике, која, ипак, остаје главни предмет на студијама музикологије.

5 У Статуту Факултета (члан 49) је прецизирано: „На Факултету се оснивају катедре за једну или више сродних ужих уметничких, ужих научних, ужих теоријско-уметничких односно ужих стручних области./Катедра се може формирати уколико на Факултету постоје студијски програми, односно модули чијим се завршавањем остварују компетенције за уже области за коју је катедра надлежна./Катедру чине сви наставници и сарадници који су изабрани у уже уметничке, уже научне, уже теоријско-уметничке односно уже стручне области за које је катедра матична." Статут је доступан на http://www.fmu.bg.ac.rs/vazna_dokumenta.php.

${ }^{6}$ То су биле примењена естетика, историја уметности, страни језици, социологија културе, једно време и психологија и педагогија. Наставници ових дисциплина формирали су засебну организациону јединицу Одељење (Члан 62): „На Факултету постоји Одељење општеобразовних односно стручних предмета./Одељење чине сви наставници и сарадници који су изабрани у уже уметничке, уже научне, уже теоријско-уметничке односно уже стручне области, за које се компетенције стичу завршавањем студијских програма за које Факултет није матичан."

${ }^{7}$ Стана Ђурић Клајн (1905-1986, рођена Ђурић, први пут удата Рибникар).

${ }^{8}$ Делатност Стане Ђурић-Клајн била је предмет изучавања Роксанде Пејовић, а посвећен јој је и један од зборника које је објавило Музиколошко друштво Србије. Сf. Роксанда Пејовић, Музиколог Стана ЂурићКлајн (историографска, есејистичка и критичарска делатност, Београд, САНУ, Музиколошки институт, Удружење композитора Србије, 1994; Роксанда Пејовић, Коментари текстова Стане Бурић-Клајн (Поводом стогодишђюиие рођења), Београд, ФМУ, Катедра за музикологију, 2008; Мирјана ВеселиновићХофман и Мелита Милин (уреднице), Стана Бурић-Клајн и српска музикологија, Београд, МДС, 2010.

9 Петар Коњовић (1883-1970). Коњовић је на Музичкој академији био редовни професор за дикцију у вокалном ставу, инструментацију, дириговање и историју позоришта. Како се 1948. године у Српској академији наука ангажовао око оснивања Музиколошког института, чији је био први директор, било је природно да учествује и у раду новооснованог Одељења за историју музике. Није међутим познато више података о овој његовој делатности.

${ }^{10}$ Никола Херцигоња (1911-2000). Музиколошки рад Николе Херцигоње осветљен је у посебном зборнику. Cf. Мирјана Веселиновић-Хофман и Мелита Милин (уреднице), Никола Херцигоња (1911-2000) - човек, дело, време (Поводом 100 година од рођења), Београд, МДС, 2011.
} 
Мило Асић ${ }^{11}$ (1950-1951), хонорарни наставник за југословенску историју музике, Миодраг Васиљевић ${ }^{12}$ (1938-1963), етномузиколог и др Марија Корен ${ }^{13}$ (1969-1972), музиколог. Први наставници, све до Марије Корен, нису имали докторате, иако је то на универзитетима у Србији у хуманистици био предуслов за избор у наставничко звање, ${ }^{14}$ и то није био израз само недостатка кадрова већ и концепта студија историје музике који је био близак совјетском ${ }^{15}$ и студије музикологије везује за високу музичку школу, а не филозофски факултет.

Оснивање Одсека за историју музике и музички фолклор било је од изузетног значаја за развој ових научних дисциплина, јер са његовим деловањем започиње континуирано школовање стручњака у овим научним областима. Почеци су били скромни. Из првих генерација школовање је завршио веома мали број студената: до школске 1961/62. године једанаест, а до краја седме деценије само још пет. Тек један део од овог броја посветио се научноистраживачком раду. Међу именима првих једанаест дипломаца налазе се и др Милош Велимировић (1922-2008), један од водећих светских византолога који је радни век провео у САД, македонски угледни музиколог др Драгослав Ортаков (1928), доајени српске музикологије др Роксанда Пејовић (1929-2018) и др Димитрије Стефановић (1929) и др Марија Корен, која је после школовања у Београду и Лењинграду, и почетка педагошке каријере на београдској Музичкој академији, рад наставила на Филозофском факултету у Љубљани.

\section{Седамдесете и осамдесете}

Динамичнији развој Одсека може се пратити од почетка седамдесетих година када наступају бројне промене. На катедри су ангажовани за предмет историја југословенске музике Властимир Перичић ${ }^{16}$ (1971-1993), за општу историју музике др Мирјана Веселиновић Хофман $^{17}$ (1973-2016), др Роксанда Пејовић (1975-1995), др Надежда

\footnotetext{
${ }^{11}$ Мило Асић (1916-1980).

12 Миодраг Васиљевић (1903-1963).

${ }^{13}$ Марија Корен (1937, удата Бергамо). Јубилеји Марије Бергамо обележени су у словеначком Музиколошком зборнику, а интервју са ауторком објављен је и у часопису Нови Звук. Cf. Zoran Krstulović, Bibliografija Marije Bergamo, Muzikološki zbornik, XLIII/2, 2007, 399-456; Leon Stefanija, „A Conversation with Marija Bergamo”, New Sound, 35, 2010, 5-16.

${ }^{14}$ Први докторат наука у области музикологије стекао је Милоје Милојевић (Праг, 1925), управо да би добио одговарајућу компетенцију за рад на Филозофском факултету Универзитета у Београду.

${ }^{15}$ После рата, 1945. године, на Музичкој академији је усвојен совјетски, седмогодишњи систем школовања. Управо 1948. године долази до повратка на ранији концепт наставе.

${ }_{16}$ Властимир Перичић (1927-2000). О музиколошком раду Властимир Перичића више у: Дејан Деспић, „Разговор са Властимиром Перичићем”, Нови Звук, 2, 1993, 5-10; Марија Масникоса, „Музиколошки опус Властимира Перичића", Нови Звук, 10, 1997, 33-46.

17 Мирјана Веселиновић-Хофман (1948). Њена делатност осветљена је у интервјуу: Tijana Popović Mlađenović, „Living One's Own Thought Experience with Music and Musicology - Interview with Mirjana Veselinović-Hofman", New Sound, 41, 2013, 5-25. Мада је у прегледима оваквог типа незахвално издвајати појединачне доприносе, међу члановима Катедре постоји недвосмислени консензус да је за развој Катедре за музикологију допринос Мирјане Веселиновић-Хофман био фундаменталан. Она је била руководилац свих научних пројеката Катедре, дугогодишњи шеф Катедре, њен представник у Матичном (научном) одбору надлежног Министарства, покретач и уредник интернационалног часописа Нови Звук, предани и посвећени
} 
Мосусов $^{18}$ (1977-1994), др Соња Маринковић ${ }^{19}$ (од 1981); за естетику др Зоран Гавриловић (1970-1971), потом предмет мења име у историја филозофије са естетиком и предаје га др Милан Дамњановић ${ }^{20}$ (1978-1989); за музички фолклор, поред др Драгослава Девића ${ }^{21}$ (1962-1990) и др Димитрије Големовић ${ }^{22}$ (од 1979). Број студената се значајно повећао и о томе уверљиво сведочи податак о броју свршених студената: од оснивања до краја 1996. на музикологији је дипломирало 79 студената, а до 2017. године студије је завршило укупно 218 студената.

У школској 1977/1978. години студије музикологије, због обима, постају петогодишње, тако да завршна, пета година студирања бива посвећена изучавању музике $\mathrm{XX}$ века, опште и југословенске, уз још само два предмета на години (Методика теоријске наставе $^{23}$ и Историја филозофије са естетиком), а постојао је и једногодишњи апсолвентски стаж за израду дипломског рада. Курикулум је обухватао 54 двосеместрална предмета, међу њима главне предмете, општу (током пет година) и југословенску историју музике (током три године) са обавезном израдом осам годишњих семинарских радова из свих главних предмета. Студије музикологије су такође имале разуђен програм из области музичке теорије (музички облици, контрапункт, хармонија са хармонском анализом), затим оркестрацију (факултативно и вежбе у компоновању), практичне музичке предмете (клавир, свирање партитура, хор, солфеђо), као и групу предмета из области хуманистике: естетика/историја филозофије/примењена естетика, социологија културе, психологија, педагогија и страни језик), као и предмете основи општенародне одбране и марксизам. Током година донекле је смањиван број предмета како би се студенти растеретили и повећала ефикасност студија, али никад није пао испод 44 (односно 88 једносеместралних). Захтеви дипломског рада на музикологији су били врло високи (обим се кретао од стотинак до више од двеста страница текста), неретко су имали изразити истраживачки карактер и давали оригиналан допринос дискусији о разноврсним питањима опште и националне историје музике. Да је тај квалитет био уочен потврђује едиција од шест дипломских радова које су објавили Факултет и Удружење композитора Србије. ${ }^{24}$

педагог под чијим менторством је одбрањен велики број дисертација и постављена широка лепеза разноврсних специјализација чланова Катедре (и не само на београдској високој школи). Стандарди које је поставила својим научноистраживачким радом за све представљају узор и професионалну обавезу. То су разлози због којих је прослава јубилеја Катедре првенствено осмишљена као својеврсно одавање почасти најзаслужнијем. О томе сведочи и наслов обимног зборника који је Катедра објавила поводом њеног јубилеја, седамдесет година живота. Cf. Sonja Marinković et al. (Eds.), Essays in Honor of Prof. Dr. Mirjana Veselinović-Hofman/Izazovi savremene muzikologije. Eseji u čast prof. dr Mirjane Veselinović-Hofman, Belgrade, Faculty of Music, 2018.

18 Надежда Мосусов (1928). Мада је професорка Мосусов била стално запослена у Музиколошком институту САНУ, њен вишегодишњи педагошки ангажман на Катедри за музикологију оставио је дубок траг.

19 Соња Маринковић (1954).

${ }^{20}$ Милан Дамњановић (1924-1994).

21 Драгослав Девић (1925-2017).

22 Димитрије Големовић (1954).

23 Садржај предмета се односио на методска питања наставе низа предмета у средњој музичкој школи, међу којима је била и историја музике. После реформе, методички курсеви су значајно развијени, а питања методике наставе историје музике изучавају се као посебан двосеместрални предмет на мастер студијама.

24 У питању су дипломски радови Марије Ковач, Зоране Радић, Милице Гајић, Сање Грујић, Снежане 
Резултати дипломских и магистарских истраживања су публиковани и у тада водећим музиколошким часописима (Звук, Нови Звук, Зборник Матице српске за сценске уметности и музику). Но, промене се пре свега огледају у настојањима Катедре да се студенти од првих година студија усмеравају на научноистраживачки рад, тако да је овај одсек поставио нуклеус будуће научне делатности на Факултету музичке уметности. Само су на њему (све до 2005. године, када је донет нови Закон о високом школству) примењивани научни критеријуми за изборе у звања и интензивно је развијана научноистраживачка делатност.

Да би се обезбедила могућност објављивања успелих семинарских радова, есеја и осврта студената, на Факултету је покренут студентски часопис Музика и реч (од 1971. до 1979. изашло је једанаест бројева часописа), који су уређивали углавном студенти музикологије и етномузикологије. Млади музиколози објављивали су радове и у часопису Универзитета уметности 4Ф. Потом је штампање радова настављено у тематским зборницима.

Два зборника су се појавила 1985. године: први је био под насловом Барок и рококо; други зборник чине радови посвећени делу Стевана Христића, а издат је поводом обележавања стогодишњице композиторовог рођења. Трећи зборник, из 1986. године, обухватио је радове посвећене композиторском стваралаштву Петра Крстића. Четврти зборник појавио се 1988. године, а поводом прославе годишњице Факултета, те је под насловом Музика у античким и средюовековним еповима објединио радове студената рађене на првој и другој години студија. Као домаћин XV сусрета музичких академија Југославије, Факултет је 1989. године објавио зборник радова студената из целе земље, који су читани на сусретима музиколога, етномузиколога и теоретичара музике 1988. Наредна два зборника посвећена су стваралаштву Косте Манојловића (1990) и Станислава Биничког (1991).

Да би се што већем броју успешних студената омогућило да по окончању студија наставе да се баве научноистраживачким радом на магистарским и докторским студијама, а потом и самосталним научноистраживачким радом, при катедри је основан Звучни архив који омогућава заштиту и научну обраду звучног материјала, рукописа и преписа нота југословенских композитора и богате снимљене грађе за етномузиколошка проучавања. Теме последипломских и докторских студија на музикологији и етномузикологији део су истраживачких пројеката финансираних од стране надлежног министарства чији су носиоци чланови Катедре. Први пројекти су имали називе Развој и остварења српске уметничке музике и Карта дијалеката музичке и орске народне традиције Србије. Катедра континуирано учествује у пројектима министарства за научна истраживања и до сада је реализовала низ пројеката са темама: Историја и естетика српске музике, 19931996; Српска народна и уметничка музика, 1997-2000; Српска музика и европско музичко наслеђе, 2001-2005; Светски хронотопи српске музике, 2006-2010, Идентитети српске музике у светском културном контексту, 2011-2017. Подршка коју надлежно 
министарство даје овим основним истраживањима омогућава врло обимну продукцију. Објављују се индивидуалне и колективне монографије, зборници радова са научних скупова, часопис Нови звук/New Sound, зборници студентских радова, мастер и дипломски радови студената музикологије. Организују се међународни и домаћи скупови, гостовања значајних светских научника и професора и тако ствара платформа за разгранату међународну промоцију резултата истраживачко рада.

Катедра је почев од 1987. године бијенално организовала међународни научни скуп Фолклор и ґегова уметничка транспозиција и тим поводом издавала зборнике радова Фолклор и његова уметничка транспозищија I-III, 1987, 1989, 1991).

Априла 1995. године скуп је као национални одржан по четврти пут, а радови су објављени под именом Музика кроз мисао (2002). Пети скуп је организован под именом Фолклор - музика - дело/Folklore - Music - Work of art са темама Фолклор и негова уметничка транспозиција и Идентитет и алтеритет уметничког дела, а радови су објављени у посебним зборницима на српском и енглеском језику. У 1997. години одржан је нови скуп са темом Изузетност и canocmojaњe/Exclusivity and Coexistence, на којем је учествовало преко 40 референата из земље и иностранства.

У сарадњи са Удружењем композитора и музичких писаца Србије организована су два музиколошка скупа Милоје Милојевић - композитор и музиколог 1986. године и Аспекти интерпретаџије, 1988, после којих су такође штампани радови у истоименим зборницима. Катедра је суорганизатор скупа посвећеног делатности Павла Стефановића 2016. године, а зборник је штампан 2017.

\section{Деведесете}

Нова етапа развоја одсека почиње деведесетих година прошлог века. Она је обележена значајним повећањем броја наставника и сарадника и поменутом променом имена одсека и катедре у Одсек/Катедру за музикологију и етномузикологију, променом која није била само формалне природе, већ је, коришћењем у свету уобичајеног имена научне дисциплине, недвосмислено изражавала научни карактер студија. На Катедри су за историју музике запослени др Тијана Поповић Млађеновић (од 1989), др Марија Масникоса (од 1990), др Весна Микић (1991), др Драгана Стојановић-Новичић (од 1992), др Татјана Марковић (1996-2012), др Ивана Перковић (од 1995), др Драгана Јеремић Молнар (од 2004), др Биљана Лековић (рођ. Срећковић, од 2008), др Ана Стефановић (на Факултету запослена од 1991, од 2017. члан Катедре за музикологију на којој је и пре овог избора била ангажована у настави на главним предметима). Као сарадници ангажовани су др Ивана Миладиновић Прица (од 2008), Марина Марковић (од 2012), др Ивана Петковић (2012), др Радош Митровић (од 2014) и Стефан Цветковић (од 2011), као и један број студената магистарских и докторских студија (Валентина Радоман, Адриана Сабо, Бојана Радовановић, Неда Колић, Милица Петровић).

У корпусу предмета који припадају хуманистици, а налазили су се у склопу Катедре за музикологију били су ангажовани наставници: за Примењену естетику и теорију 
уметности др Душан Пајин (1990-1996), др Миодраг Шуваковић (1996-2015) и др Санела Николић (од 2012). Психологију и педагогију предају др Зоран Јовановић (1950-1956), др Светозар Ранчић (1951-1952), др Ксенија Радош (1974-2005), др Властимир Миљковић (1975-1976), др Тијана Косановић (1977-78), и др Бланка Богуновић (од 2006). Историју уметности предају др Станислава Коларић (1948-1949), Владо Мађарић (1950-1959; 1962 1963), др Павле Васић (1964-1976), Бранка Пецарски (1978-1979), Живко Брковић (198083), Христина Лисичић (1984-86), др Слободан Мијушковић (1986-1990), др Јасмина Чубрило (2002-2013), др Никола Дедић (од 2014). Основе науке о друштву и социологију уметности предају др Ана Јурић-Жилић (1960), др Милош Самарџија (1960-1962), др Милан Ранковић (1964-1973), др Смиљан Лазин (1974-87) и Рада Дрезгић (од 2008); Енглески језик Зорица Деспић (1974-1976), др Илеана Чура (1977-1979), Вишња һоровић (1979-1990), Милена Ердељан (1980-1981), мр Милијана Гркајац (од 1993), Јелена Спремић (од 2008); Немачки језик Раде Павићевић (1950-1955) и Зорана Козомарић (од 1993).

За развој курикулума на музикологији значајне промене у програму и називу главних предмета наступају 1994. и последица су распада СФРЈ. Градиво које је изучавано у склопу југословенске историје музике у знатно мањем обиму бива укључено у предмет Општа историја музике, а предмет Југословенска замењује Национална историја музике. На главним предметима формирају се посебни курсеви на којима се изучавају одлике стилова и епоха и развија пракса специјализација појединих наставника за одређене области, како је то уобичајено у историји уметности. Тежи се даљем растерећењу изузетно захтевног плана студија који остаје петогодишњи са додатном апсолвентском годином.

\section{Прве деценије новог миленијума}

Ка даљој ефикасности студирања (да ли и квалитету?) иде се са болоњском реформом за коју је основ дао Закон о високом образовању из 2005. године. Сви универзитетски програми трансформисани су у два циклуса са три нивоа студија: бачелор (основне академске студије), мастер и докторске са укупно 300 (бачелор и мастер) +180 кредита (докторске). На Факултету сви програми добијају идентичну структуру где први циклус обухвата $240+60$, а други 180 кредита. На Факултету је искоришћена и могућност организовања специјалистичких студија (60 кредита после мастер студија у склопу другог нивоа), али је оцењено да на музикологији оваква врста специјализације није потребна. Међутим, наставници Катедре дају значајан допринос и овом виду студија укључивањем у специјалистичке уметничке програме на којима изводе већину академскоопштеобразовних предмета и воде методолошке курсеве.

Процес имплементације болоњских принципа је дуг и континуиран. Подразумевао је модуларизацију предмета и имплементацију кредитног система. Сви предмети су трансформисани у једносеместралне модуле са завршним испитом после сваког семестра. Групи главних предмета на прве две године додељено је 24 кредита, а на завршне две године по 40 кредита. Колико су промене биле корените може да покаже упоредни преглед 
структуре курикулума пре и после реформе. Петогодишње студије имале су 46 двосеместралних предмета, међу њима 54 једносеместрална курса из главних предмета опште историје музике и националне историје музике. После извршене реформе студијски програм музикологије је постао једноставнији. Дипломски/мастер рад је део пете године студија, постоји (само) 30 курсева главног предмета (са семинарским радом), а сразмерно је смањен и број курсева из других предмета, но задржани су концепт програма и све његове дисциплине. Повећан је број студената (програм је акредитован за 10 студената на прва два нивоа и 4 на докторским студијама). По новим акредитованим студијама уписана је генерација 2008/2009. године. У другом акредитационом циклусу извршене су одређене промене а суштинска се односи на 'укрупњавање' курсева јер се (како искуство на целом универзитету говори) у хуманистици парцијализација није добро показала.

После деведесетих година прошлог века интензивира се научноистраживачка и издавачка делатност на Катедри. Традиционални међународни скуп, после неколико година паузе, одржава се наизменично са округлим столовима или скуповима националног карактера, ништа мање значајним јер су посвећени важним питањима везаним за историју српске музике. Са свих скупова објављени су зборници радова, било двојезично, било само на енглеском језику: Музика и медији/Music and Media (2004), Music \& Networking (2006), Musical Culture \& Memory (2008), (Auto)Biography as Musicological Discourse (2010), Between Nostalgia, Utopia, and Realities (2012), Identities: The World of Music in Relation to Itself (2012), Music Identities on Paper and Screen (2014), Music/Image: transpositions, translations, transformations... (2018). Национални карактер имали су зборници Опера од обреда до уметничке форме (1999), Музика кроз мисао (2002), Човек и музика - у част Драгослава Девића (2003), Музиколошке и етномузиколошке рефлексије (радови са скупа одржаног 2003, 2006), Историја и мистерија музике - у част Роксанде Пејовић (2006), Мокрањиу на дар (2006), Allegretto giocoso - стваралачки опус Миховила Логара (2008), Тематски потенцијали лексикографских јединица о музичким институцчјама (2009).

На Катедри је реализован капитални пројекат Историја српске музике: српска музика и европско музичко наслеђе (2008), обиман (785 страница), проблемски конципиран поглед на разноврсна питања историјата српске музике и стила, развој жанрова и институција музичког живота. Катедра је издавач и интернационалног часописа $\mathrm{New}$ Sound/Hoви звук на енглеском (папирно издање) и српском језику (електронско издање).

Настављена је и пракса објављивања студентских семинарских и дипломских радова. Штампани су зборници Од Платона до Џона Зорна (2008), Ликови и лица музике (2010), Музиколошке перспективе 1 u 2 (2012), два електронска издања зборника радова (Музички идентитети и европска перспектива: интердисциплинарни приступ и Зборник, оба су резултат истоименог пројекта/модула, који се под покровитељством Жан Моне програма Европске уније и Министарства културе и информисања Републике Србије, и под вођством редовног професора др Мирјане Веселиновић-Хофман, одвијао на Катедри за музикологију ФМУ у Београду, 2014-2017). У 2017. овај пројекат је настављен под руководством др Марије Масникосе. Објављена је такође серија дипломских/мастер радова Иване Петковић, Игора Радете, Наташе Турнић Ђорђић, Биљане Срећковић, Иване 
Миладиновић Прица, Смиљке Милосављевић. Поводом јубилеја, у електронском виду објављени су нови изабрани радови у две едиције: Wunderkammer/Soba čudesa и Their Masters' Voice.

Чланови Катедре развијају разноврсну, богату активност и интензивно раде на афирмацији наше науке у земљи и свету. А да њихова активност јесте призната можда најбоље потврђују ниво међународног скупа који Катедра бијенално организује а на којем узимају учешће научници из целог света, као и плодна интернационална сарадња у склопу Еразмус+ пројеката.

\section{Коришћена литература}

Веселиновић-Хофман, Мирјана и Мелита Милин (уреднице): Стана Ђурић-Клајн и српска музикологија. Београд: МДС, 2010.

Веселиновић-Хофман, Мирјана и Мелита Милин (уреднице): Никола Херцигоња (19112000) - човек, дело, време (Поводом 100 година од рођења). Београд: МДС, 2011.

Деспић, Дејан: „Разговор са Властимиром Перичићем”, Нови Звук, 2, 1993, 5-10.

Krstulović, Zoran: „Bibliografija Marije Bergamo”, Muzikološki zbornik, XLIII/2, 2007, 399456.

Stefanija, Leon: „A Conversation with Marija Bergamo”, New Sound, 35, 2010, 5-16.

Масникоса, Марија: „Музиколошки опус Властимира Перичића”, Нови Звук, 10, 1997, 3346.

Пејовић, Роксанда: Музиколог Стана Бурић-Клајн (историографска, есејистичка и критичарска делатност). Београд: САНУ, Музиколошки институт, Удружење композитора Србије, 1994.

Пејовић, Роксанда: Коментари текстова Стане Бурић-Клајн (Поводом стогодишњице рођења). Београд: ФМУ, Катедра за музикологију, 2008.

Popović Mlađenović, Tijana: „Living One's Own Thought Experience with Music and Musicology - Interview with Mirjana Veselinović-Hofman”, New Sound, 41, 2013, 5-25.

Статут Факултета музичке уметности у Београду, http://www.fmu.bg.ac.rs/vazna_dokumenta.php

\section{Резиме}

У раду се осветљава делатност Катедре за музикологију Факултета музичке уметности поводом јубилеја, 70 година од оснивања. Циљ је да се покажу промене у концепту студија музикологије, представе наставници Катедре и њихова научно-истраживачка и педагошка делатност. Развој Катедре сагледан је кроз четири етапе. Прва обухвата време од оснивања 
до почетка седамдесетих година, друга је обележена програмским заокретом у настави која се односи на националну традицију, заокретом до којег долази после распада СФРЈ (промене наступају 1994); трећа је означена почетком примене принципа болоњске реформе (2008) и последња почиње са структурним променама у организацији Катедре када су из њеног састава изузете друге хуманистичке дисциплине (2016). Осветљене су најзначајније промене у наставним плановима и програмима студија музикологије, а посебна пажња посвећена је издавачкој делатности Катедре. 